\title{
Miranda
}

Revue pluridisciplinaire du monde anglophone /

Multidisciplinary peer-reviewed journal on the English-

speaking world

$8 \mid 2013$

In Umbra Voluptatis : Shades, Shadows, and their

Felicities / Film Adaptations, New Interactions

\section{Chaste or chased? Interpreting Indiscretion in Tennessee Williams' Suddenly Last Summer}

\section{Marie Pecorari}

\section{(2) OpenEdition}

\section{Journals}

\section{Electronic version}

URL: http://journals.openedition.org/miranda/5553

DOI: $10.4000 /$ miranda. 5553

ISSN: 2108-6559

\section{Publisher}

Université Toulouse - Jean Jaurès

\section{Electronic reference}

Marie Pecorari, "Chaste or chased? Interpreting Indiscretion in Tennessee Williams' Suddenly Last Summer", Miranda [Online], 8 | 2013, Online since 28 June 2013, connection on 16 February 2021. URL: http://journals.openedition.org/miranda/5553; DOl: https://doi.org/10.4000/miranda.5553

This text was automatically generated on 16 February 2021

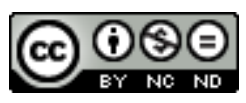

Miranda is licensed under a Creative Commons Attribution-NonCommercial-NoDerivatives 4.0 International License. 


\title{
Chaste or chased? Interpreting Indiscretion in Tennessee Williams' Suddenly Last Summer
}

\author{
Marie Pecorari
}

1 The Venus flytrap is the first detail singled out and brought to the spectator's attention in the opening scene of Suddenly Last Summer. Taking Doctor "Sugar" on a tour of Sebastian's "well-groomed jungle" (102) ${ }^{1}$, Violet Venable zeroes in on this "insectivorous plant", a rather unusual flower but not out-of-place in a symbolical garden said to resemble "organs of a body, torn out" (101). It visually incorporates memories of the poet's untimely end the year before, and establishes the overtly nonrealistic atmosphere of a "Gothic dialectics of overrefinement and wildness, fastidious artifice and dangerous nature" (Gross 229). The Venus flytrap can be viewed as a rather transparent metaphor ${ }^{2}$ for Sebastian himself ${ }^{3}$ : predatory yet vulnerable, perfectly handsome in a delicate, feminine way like the goddess of beauty, and also hungry for flesh, in his case, adolescent boys instead of flies. Te metaphor of hunger to reflect Sebastian's carnal lust is indeed later rendered explicit by Catharine Holly, who likens her cousin's treatment of boys to that of "items on a menu" (118). Sebastian's decision to stop feeding on others is also presumed to have led to his death, as if from a lack of nourishment ${ }^{4}$. Another representation of Sebastian's death follows closely the example of the Venus flytrap, with Violet reminiscing about their trip to the Enchanted Islands to watch the hatching of sea-turtle eggs and their subsequent maiming and killing by birds of prey (echoed later by the description as the street-urchins killing Sebastian as "a flock of featherless little black sparrows" (147)). But the image is reversible (the flower as well as the sea-turtles), as the Venus flytrap can also be read as a representation of Sebastian the sexual predator falling victim to a more literal form of cannibalistic ingestion. The two-fold, opposite yet non-contradictory interpretations conveyed by the symbolism of the flytrap reflect deeper hermeneutic questions presented in the play, which seems to rely on those ambiguities to regularly put on hold the elucidation process. The reputation of the dead poet is filtered through the memories of two women warring over their antagonistic notions of the truth, Violet 
standing for "artistic" and Catharine for "ethical" values ${ }^{5}$ (Gross 243). While Catharine is not concerned with Sebastian's status as an author, Violet seeks to protect her son's memory in the name of his literary legacy. Violet views the art and life of an author as a continuum, refusing to separate them, which leads her to try to maintain control on all interpretations of her son's actions, as if they could metonymically undermine the value of Sebastian's body of work:

Sebastian was a poet! That's what I meant when I said his life was his work because the work of a poet is the life of a poet and-vice versa, the life of a poet is the work of a poet, I mean you can't separate them, I mean. (103)

2 The absence of separation, leading to a lack of discernment, will be used as the starting definition of indiscretion, alongside the more traditional use of the term as an invasion of privacy ${ }^{6}$. Given Violet's central assumption about the necessary conflation of biography and work, Suddenly Last Summer can be read as an interrogation on authorship and the creative process. It is hard to resist the temptation to read the play in the light of Williams's own stance on the matter, articulated in his non-fictional works, as well as more obliquely in some of his fiction. As a matter of fact, his claim that "all good art is an indiscretion" in the Memoirs is followed by a playful refusal to explain and comment on his own works: "I could devote this whole book to a discussion of the art of drama, but wouldn't that be a bore? (144)

The play meanders adroitly to arrive at the same result that this rhetorical question put bluntly: waving a promise only to take it away. This article attempts to break down this strategy of retreat. The play is structured around the contrast of two women standing for opposite conceptions of the truth (VIOLET: "my truth-[...] the truth" " (103)), so that the outcome of the fight (whether or not Catharine will be returned to a normal life and regain her freedom) hinges on the result of the epistemological struggle. The confrontation may seem somewhat Manichean, which can be viewed as a concession to Gothic generic codes (Gross 229): Violet is older, more established, manipulative, and her physical frailty and recent stroke better highlight her mental toughness and determination to crush her niece. Whereas Catharine is younger, in an awkward social position as the unmarried daughter of an impoverished family, and is trapped, though perfectly aware of the shenanigans of her relatives (her sense of isolation is onomastically signified, Catharine meaning "pure"). Her mother and brother keep her under pressure to comply with her aunt's wishes, and at the start of the play, she lives in an insane asylum paid for by Violet in an effort to prevent her niece from "babbling", that is to say from revealing and spreading her eye-witness account of Sebastian's last summer and death. Violet blackmails the doctor she has hired to perform a lobotomy on Catharine -i.e., to sentence her to a virtual mental death-, threatening to withdraw the funding she has promised him for research if he fails to go ahead with the operation. But the doctor refuses to yield to the older woman until he has heard Catharine's version of Sebastian's death, the truth of her account being given scientific validation by means of an "injection" supposed to compel the patient to tell the truth:

It makes you tell the truth because it shuts something off that might make you able not to and everything comes out, decent or not decent, you have no control, but always, always the truth! (121).

The premise of the revelation seems somewhat illogical (Gross 234-235), as Catharine is urged to reveal a truth she has already been spreading to the point of needing to be hushed. Yet it is a discovery for the spectator, and it may be a full disclosure for all 
other characters, as Catharine's previous babbling seems to have been either fragmentary, mediated, or expurgated. Violet's previous contact with Catharine's account was indeed in "a watered down version, being too ill to go to hear it directly" (110), with the Doctor stressing that the talking cure he is about to administer compels the patient to tell an exhaustive account, thus equating truth with totality: "The absolutely true story. No lies, nothing not spoken. Everything told, exactly" (134). Catharine's truth is validated tentatively albeit ambiguously: "we ought at least to consider that the girl's story could be true" (148), the doctor concludes in the last lines of the play, displaying a masterful command of modality. Violet's defeat seems nonetheless unmitigated -thus leading to an ending about as clear-cut as the two female characters, who appear to be allegorical embodiments of lucidity and blindness, with Catharine occupying the entire verbal space and leaving Violet unable to riposte.

5 The biographical details provided by Catharine about Sebastian are technically not an indiscretion, as he acted publicly, in broad daylight (white is the dominant color in the death tale). Only his mother, who failed to realize his true inclinations and her own role as bait for his sexual pursuits, could consider it to be one ${ }^{7}$. It is Violet's insistence on leading her life in the company of her son as art that results in her covering over the fault lines in her son's biography, albeit somewhat unconsciously. But in trying to connect Sebastian's life and art she remains aware of the aesthetic relation between the two, when Catharine eliminates it. The younger woman views the truth about Sebastian's life and death in absolute terms and cares little about the harm it could inflict on his reputation, as dearly as she loved him as a person. From Catharine's account, we may infer that Sebastian committed a form of sacrificial suicide, in keeping with the Christ-like images pervading the play (Clum 130-133) and his saintly namesake, and therefore that his was a voluntary (if possibly unplanned), artistic death. Not an additional speck of dust on the trail of debris left by common people, but the finishing touches put on a constructed, well-thought out artwork, to reprise Violet's own comparison. ${ }^{8}$ Yet Catharine remains blind to her cousin's possible motivations, and fails to understand what could have led him to turn down her help and rush to his death. Never does it occur to her that he may have wanted to die a calculated death. In other words, she glosses over the issue of artistic creation, just as Williams does in the Memoirs, though for different reasons, when he bares his private self while refusing adamantly any attempt to establish explicit connections between his biography and writings. As intelligent and lucid as the character may be presented elsewhere, Catharine fails to grasp the depth of the project uniting the mother-son twin-like pair and their obsession with making their lives a perfect reflection of his art $^{9}$. In a way, Catharine's character serves as a deterrent: even though she is the agent through whom the truth is presented as scientifically revealed, following her perspective leads to a dead-end, that is to say an absence of answer to the question initially asked by the play about art and life. Because despite the misguided attempts to have her pass for mentally deranged, and her problematic past, she remains staunchly on the side of life, at least in her interpretation of her cousin's gesture. In fact, regardless of the actual veracity of Catharine's account -a question that Williams purposefully refrains from answering-, she manages to turn the struggle into a realistic fact-checking endeavor. Violet's worship of her son leads her to overlook the darker aspects of his life, which may have worsened the summer he died, but do not seem to have started then. Significantly, when Violet has the doctor look at two pictures of her son taken twenty years apart, both of them show a masked Sebastian: 
Here is my son, Sebastian, in a Renaissance pageboy's costume at a masked ball in Cannes. Here is my son, Sebastian, in the same costume at a masked ball in Venice.

(109)

6 This being a possible allusion to her inability to see behind and beyond the disguise. The situation would still be relatively simple were Catharine's perspective reliably realistic. Yet it is anything but that, as Williams creates a chiasmatic disjunction between the content of each account and its expected discursive mode. To the proponent of the aesthetic dimension, he grants a desire to nail down the facts in straightforward fashion, while having her praise the virtues of a brand of ethereal art. And he has the representative of the ethical side, seemingly uninterested in poetry, tell her version of the story not only in a highly lyrical style, but with enough manifest imagination to betray its detachment from actuality. It is Violet, who maintains that the aesthetic vocation is a continuum between life and art, who now demands a separation (that Sebastian be judged not aesthetically, but factually), and cannot bear to hear her niece spin her fanciful yarn. Following the logic of Catharine's mother, who sides with Violet, the departure from actuality is analogous to horror: "MRS. HOLLY: don't repeat that same fantastic story! [...] don't repeat that horrible story again!" (121) (emphasis mine). Williams makes it clear that the story is indeed to be interpreted metaphorically:

It horrified me, the film [adapted by Joseph Mankiewicz in 1959]...I was so offended by the literal approach because the play was metaphorical...It was a sort of poem, I thought (Brown 274)

7 A closer analysis reveals the presence of fragments and images from other myths and literary works, notably Hart Crane's (Siegel, and Gross 246-51). The plausible interpretation being that Williams meant to extoll the superior powers of fiction over journalistic or realistic description. This represents a counterintuitive reasoning in regard to the dichotomy commonly established between facts and fiction in connection with truth. Although Catharine fails to take into account her cousin's vocation, it seems as if she were ironically given artistic license in her portrayal of the death scene, filling in the blank left by Sebastian's loss of creativity, and endowed with a convincing sense of copia he never seemed to possess. This does not invalidate her account per se, only her professed viewpoint. That Williams felt the need to express his own views so sinuously, turning Catharine into an unlikely and unwilling poet, appears to illustrate his ambivalent position regarding the absence of separation between art and life: "Of course it is a pity that so much of all creative work is so closely related to the personality of the one who does it." (Williams 2009, 73). What he does oppose is the attempt to interpret or invent connections, as if they could be discovered and were not the result of a mysterious, inaccessible process:

the passions and images of it that each of us weaves about him from birth to death, a web of monstrous complexity, spun forth at a speed that is incalculable to a length beyond measure, from the spider-mouth of his own singular perception. (ibid 73)

8 Violet remarks her son would take nine months, "the length of a pregnancy" (104) to gestate his yearly poem, before giving birth to it over the summer with the help of his midwife mother. However conventional the metaphor of artistic creation as giving life may be, it remains a reformulation of Williams' image of the spider. Because the creative process is an organic kind of maturation working in mysterious ways, attempting to map out the relationship between an author's biography and work, 
especially in a direct manner, is doomed to fail-and is about as hopeless an enterprise as re-membering a dead poet.

9 So let us return to Violet's assumption about the absence of separation between art and life, however flawed, as it seems to better represent Williams' stance. First, let us analyze the reasons behind her refusal to accept Sebastian's death: she finds his presence near the public beach where he was murdered and his physical closeness to the street urchins hard to believe, out of touch with the usual decorum of her son's life (or her own partial vision of it):

After all I've told you about his fastidiousness, can you accept such a statement? [...]

That Sebastian would go everyday to some dirty free public beach near a harbor? A

man that had to go out a mile in a boat to find water to swim in? (139)

10 She also makes less than thinly veiled allusions to Catharine's role, accusing her of being in love with her son, and contributing more or less directly to Sebastian's death. And she cannot imagine that her son would have considered suicide without having her at his side; the fact that he went away without her constitutes no less than a "[breach] of [their] covenant" (138). Yet she is haunted by her son's fascinations: his Venus flytrap she is letting wither away, as she cannot bear to feed it; the sea-turtles they saw on two occasions: first the females laying their eggs and burying them in the sandanother image of labor-then the young coming out and being torn apart by vultures. She is also unable to see the metaphorical connection between his aesthetic tastes and his chosen way to die. Violet's devotion to her son and blindness to his sex life is ironically stressed by Williams, who highlights the discrepancy between the mother's vision of her son as a divine, Christ-like creature and his actual self ${ }^{10}$ : when she shows the doctor a volume of Sebastian's poems, the stage direction indicates that she looked like she was "elevating the Host before the altar. [...] Her face suddenly has a different look, the look of a visionary, an exalted religieuse." (103-104). In insisting that her son should be viewed as "chaste", i.e. sexually pure, and not chased", i.e. a sexual prey, though she ultimately concedes his attractiveness made him the object of many a potential lover's pursuit, Violet cannot reconcile the fact that in order for Sebastian to be chased, he could not have been "c-h-a-s-t-e". The homophony of the two signifiers can only reflect the semantic opposition of their respective reference in that context, and uttering a word can prove diabolically slippery. So that even though Violet's original intuition about art and life corresponds to that of Williams, she essentially misinterprets it. As a matter of fact, any interpretation of the connections, especially on the part of a reader who is not the artist himself (and even then), can only be inaccurate and partialalthough we have to consider that Catharine's vision may fill that role. To compound the irony, Williams has Violet take up his own metaphor of the spider web: "A poet's vocation is something that rests on something as thin and fine as the web of a spider" (138). It is either self-parody, or a mildly sarcastic outlook on the character, who might have (mis)read Williams' own essays and Memoirs, like a number of Williams' followers who sought answers about his life in his work and vice versa, despite his warnings. So that ultimately, Violet's stance and the obvious discrepancy between her imagination and the reality she tries to mold in order to fit her vision, is as unsatisfactory and unreliable as Catharine's from a factual perspective.

11 Another conclusion could be drawn by displacing the perspective and looking not at the nature of the diverging accounts, but at their scope: Violet, both a maternal and sisterly figure, stresses her closeness to her son, and their mutual existence as the non- 
hierarchical components of an indivisible pair: "We were a famous couple. People didn't speak of Sebastian and his mother or Mrs. Venable and her son, they said 'Sebastian and Violet, Violet and Sebastian"' (111). Despite her lack of lucidity, Violet can be considered to have a chronologically thorough knowledge of her son's development from birth to before the final journey leading to his death-the death scene being a human reenactment of the founding episode of animal savagery on the Encantadas. Catharine, on the other hand, had only intermittent access to her cousin, and the brief period preceding his death was the only moment of actual togetherness with Sebastian, one woman having replaced the other in the role of the poet's bait and "procurer". Catharine's perspective on her cousin can then be described as metonymic, while Violet's, however naive, is more thorough; she is less likely to generalize from a single episode and has a better grasp of the eventful existence of her son. She recounts an anecdote where Sebastian had previously abandoned her to stay at a Buddhist monastery and lead a frugal, self-denying life, before concluding: "I got him through that crisis too" (108), implying these crises were not infrequent after the founding, metaphysical episode of the sea-turtles. She enigmatically describes her life with him as a "world of light and shadow"-an image whose semantic flexibility includes the possibility of recurring melancholy episodes, and of either a juxtaposition of two contradictory facets or their on-and-off succession. It may also be an unconscious visual embodiment of her selective awareness, tending to retain the brighter spots and overlook the darker aspects. Violet's perception of her son is panoramic in scope, yet distorted by shortsightedness, as she misses out on clues that doom her interpretation of the broader picture. Williams seems to give a metaliterary key to her perceptive defect: relying on Melville's account of the Encantadas, she had attempted to reenact her reader's memories (e.g., travelling on "as close as possible to the sort of boat that Melville must have sailed on" (104)) and had been surprised to realize the author had edited out the more gruesome aspects of the location, choosing to illustrate the onomastically correct (yet incomplete) truth about the Enchanted Islands: "we saw something Melville hadn't written about" (105).

Does Williams-to reprise an eyesight metaphor recurrent in his Memoirs-then side with myopia or magnified tunnel vision? Neither, apparently. The intuitive conclusion, based on Williams's more well-known metatexts, would favor the second solution. To use an obvious reference point, the preface to The Glass Menagerie mentions the notion of "transformation" as an antidote to the "photographic" in art, and elsewhere Williams uses the more explicit "distortion" tendencies favor a clear-cut domination of the victim over her oppressor, it would be misleading to anticipate an analogous polarization and imbalance in the treatment of truth. It seems Williams uses Catharine as "bait" to eventually bow out of an actual resolution: while he rejects the exhaustive ambitions of realism, he also expresses his wariness toward metonymy. The trope may efficiently help depict a single, dramatic episode, but whether that moment can be extended to the macrocosmic level is another story (literally). Here is how he articulates his cautiousness in the short story Hard Candy:

In the course of this story, and very soon now, it will be necessary to make some disclosures about Mr. Krupper of a nature too coarse to be dealt with very directly in a work of such brevity. The grossly naturalistic details of a life, contained in the enormously wide context of that life, are softened and qualified by it, but when you attempt to set those details down in a tale, some measure of obscurity or indirection is called for to provide the same, or even approximate, softening effect 
that existence in time gives to those gross elements in the life itself. When I say that there was a certain mystery in the life of Mr. Krupper, I am beginning to approach those things in the only way possible without a head-on violence that would disgust and destroy and which would actually falsify the story. (Williams 1985, 355) (emphases mine)

13 Yet for veracity to depend as much on presentation mode as on actual content, as suggested in the quote, the prerequisite is to have an omniscient narrator who can cut, paste, and frame at will, having access to all sides of the story. To falsify, in other words, to cheat the reader, requires an ability to consciously breach authorial ethics, which neither woman is placed in a position to do, due to their aforementioned skewed vision. So that Violet's attitude, which initially looks like it may correspond to the "softening effect" described, cannot be validated, as it stems from ignorance and has little to do with aesthetic/ethical choice, although her discourse is imbued with these values.

Much has been made of Sebastian's absence and evanescence, even if the play is centered around him. The contradictory accounts contribute to this effect, leaving little certitude about his possible identity and biography:

The break represented by Sebastian's movement from Violet to Catharine becomes a radical shift in the nature of his identity, a break so profound that the audience cannot constitute a coherent picture of Sebastian Venable. Rather than reconciling these divergent aspects, the play builds itself around this very rupture in Sebastian that makes a coherent character impossible. (Gross 239)

The play could be viewed as an attempt to dramatize the inherent failure of the epic mode in the theatre when trying to portray a character without the help of a performer's live presence-a failure in that only a series of fragments or details can be presented, inducing a dismemberment of the body, as the whole slips away when confronted with the necessity to follow the rules of mimesis, i.e., selection ${ }^{12}$. This would be illustrated in the prevalent images of physical violence culminating in the poet's very disappearance: there is indeed no-body, no material proof at the end of Catharine's story. The fantasy of indiscretion is based on the illusion of a possible absence of choice and separation (in other words, neutrality, or objectivity), which in fact results not in a clearer picture but in an indeterminate muddle-like Sebastian's garden, in which the carefully classified plants have grown into a jungle ${ }^{13}$. The favored trope would be antanaclasis, a figure representing semantic inclusion, allowing the juxtaposition of meanings, at times contradictory (as in the chaste/chased pair) ${ }^{14}$. While the trope is mostly used lightheartedly to pun, it can also reveal a desire for omniscience, i.e., an all-embracing, inclusive perspective that would dispense with the filter (and thus limitations) of an individual focus. When Catharine blurts out "I can't change truth, I'm not God!" (128), she ironically exposes the problématique of the play, and her misunderstanding of it. In her Platonic approach, there is a pre-existing, fixed truth that can be uncovered objectively, and she fancies herself as its faithful custodian. Williams seems to argue otherwise: not in favor of relativity either, but of the necessity to accept the presence of a viewpoint. Instead of searching for an absolute, godlike truth (like Sebastian's metaphysical quest ending in artistic sterility), to settle for a limited perspective. Not as a pis aller, but as a creative spur, because the framing possibilities can shift, vary, and combine in a number of manners. For Williams, truth lies not in an essence but a medium-knowing that, after all, fiction should be immune from a need for factual validation. He retains the ethical concerns 
usually associated with content-based approaches, hence the preoccupation with a possible falsification.

The eventual helplessness experienced by the characters in the play is passed on to the spectator and is rooted in Williams' refusal to provide direction, here in the form of didacticism. His demonstration about the withdrawal of the dramatic dimension hinges on another chiasmus: shutting down the dramatic mode on a representational level (i.e., eliminating a character's performative presence, thus creating the conditions for his recreation in epic mode) while refusing to resort to the set of epic tropes expected to compensate for the physical omission. In that case, and to exclude more facile means such as stage directions, screens or tricks of mise-en-scène, didacticism would mean providing a more or less contrived ending stating a definite position. For instance, ensuring Catharine's victory and the conventional triumph of good over evil-which would in turn validate one truth, and give some sense of closure to the contradictory portrayal of the artist. Although, as speculated above, the point could be that a multiplicity of accounts from various, inherently limited perspectives give a more truthful picture than a single, supposedly authoritative version, even if it comes at the price of indeterminacy. Relinquishing omniscience -letting Sebastian remain a blank, in the image of his final poem- is an inherent feature of drama. That it is achieved entirely through the epic mode, although the conflict of the two epic versions is indeed dramatic, can be viewed as a provocative exercice de style on the part of the playwright.

So what is left to know about Sebastian's work? Can conclusions be drawn about his art and life and their connection? The two non-synoptic gospels of his life may ultimately reflect their respective authors more than their subject-matter, though neither of them is made to be perceived as a liar (even Violet's perverse attempt to hush her niece is in the name of truth). The focus and point of disagreement is the poet's external behavior, which means that discussions of his possible inner life and impressions recede even further into the background.

And his work, which does exist and could be made available, is withdrawn from the spectator: after an initial tease, with Violet showing a gilt-edged volume of her son's poem without opening or reading it, Sebastian's last notebook is opened on stage, but turns out to be blank, as he had failed to write anything the summer he died.

18 The (fly)trap closes in on the spectator, with Williams staging a deceptive and disappointing chase: the play raises a question, seems to lead to a revelation, to give access to the intimate side of the dead poet. But it ultimately reiterates Williams' stance on indiscretion: that no matter how closely a reader believes he can approach the author, the latter will always prove elusive and escape his grasp. As Kevin Ohi notes about the film-and in this respect the same could be said of the original play: "Central to the sexual and spectatorial economies of the film, baiting is its key concept; it is both the film's subject and its method" (Ohi 27)

There is no way to tell whether Sebastian was a genius under the guise of a mediocre dandy, a justifiably obscure artist masquerading as superior, a truly outstanding poet whose aesthetic approach to life metonymically illustrated the higher standards of his work, or a decent craftsman. In a way, Suddenly Last Summer represents the dramatic equivalent to the flippant rhetorical question meant to deflect further investigation into a delicate matter. "Wouldn't that be a bore?". The answer, in the case of the art of drama as well as Sebastian's literary worth, is similar: of course not. When no valuable, 
definite response can be offered, Williams' riposte consists in retreating into speculation, and dramatizing the epistemic urge to parse what cannot be.

\section{BIBLIOGRAPHY}

Clum, John M. "The Sacrificial Stud and the Fugitive Female in Suddenly Last Summer, Orpheus Descending, and Sweet Bird of Youth". In The Cambridge Companion to Tennessee Williams. Cambridge: Cambridge University Press, 1997. 128-146.

Devlin, Albert J., ed. Conversations with Tennessee Williams. Jackson: University Press of Mississippi, 1986.

Gross, Robert F. "Consuming Hart: Sublimity and Gay Poetics in Suddenly Last Summer". Theatre Journal 47 (1995): 229-51.

Ohi, Kevin. "Devouring Creation: Cannibalism, Sodomy, and the Scene of Analysis in Suddenly Last Summer". Cinema Journal. 38: 3 (Spring 1999): 27-49.

Siegel, Janice. "Tennessee Williams' "Suddenly Last Summer" and Euripides' "Bacchae" ”. International Journal of the Classical Tradition. 11: 4 (Spring 2005): 538-570.

Williams, Tennessee. Collected Stories. New York: Ballantine, 1985.

---. Plays, 1957-1980. New York: Library of America, 2000.

---. New Selected Essays: Where I Live. ed. by John Bak. New York: New Directions, 2009.

\section{NOTES}

1. The page numbers refer to the Library of America edition (Plays 1957-1980. New York. 2000).

2. Williams' awareness of such apparently simplistic symbolism is not uncommon and the possible irony of the device should not be discounted. It walks a fine line between pungent efficiency and candid clumsiness, leaving the interpretation uncomfortably unresolved. Which, given Williams' tendency to play with the reader's nerves, may be the point of the device: hermeneutic indeterminacy disguised as surface Manichaeism i.e. indiscretion passing for its antonym. At any rate, the effect created here is akin to the raw primitivism of naïve art, in addition to being a common feature of the Gothic; which, on a metaliterary level, echoes the cohabitation of extremes of barbarity and refinement in the absent character. An example of Williams' self-conscious (meta-)use of the device: "In the early days of film-making the copulation of lovers could only be suggested by some such device as cutting from a preliminary embrace to a bee hovering over the chalice of a lily: and there is probably a similar bit of artifice involved in bringing up so much of Sabbatha's past history through the murmurs of the spring that cascaded beneath her Eyrie." ("Sabbatha and Solitude", in Collected Stories, 544 - a short story which also happens to include a reiteration of the claim that "all art is an indiscretion" (543)). 
3. Janice Siegel suggests the flytrap actually represents Violet ("she [Violet] fails to see that it [the flytrap] is a reflection of herself" (563)) as "Sebastian's sarcastic homage to his mother". Given the predatory nature of both mother and son, their incestuous closeness and intense narcissism, it would not be contradictory to validate either solution interchangeably. But although the film adaptation -that Siegel mostly uses as a basis for her analysis- may tilt the interpretation toward Violet, the play seems to associate the flower more directly with its owner.

4. I refer here to Catharine's hypothesis, when she interprets her cousin's sexual appetite as compensation for his self-imposed dietary restrictions: he talked about people, as if they were-items on a menu-"That one's delicious-looking, that one is appetizing," or "that one is not appetizing" -I think because he was really nearly halfstarved from living on pills and salads.(118)

5. R. Gross defines Catharine's position as "ethical" based on the combination of a positive trait (her quest for truthfulness) and an absent quality (the character's lack of concern with aesthetics). The latter reflects the notion of an incompatibility between ethics and aesthetics echoing the frontal, clear-cut opposition between the two protagonists, although I will show that the dichotomy is actually subverted.

6. In other words, the term will encompass the semantic content of the homonyms (and originally synonyms) discrete/discreet.

7. Gross (239) goes so far as to envisage that Catharine's account of Sebastian's sex life could be questioned, placing the two women's interpretations in a symmetrical position in relation to the truth -meaning they should elicit the same amount of skepticism and lead to a balanced, indeterminate judgment in the end, with no possible resolution. While this proposal may be hard to invalidate, I tend to accept that Violet is portrayed as blind to her son's personal life, because it maintains the balance (and deadlock) of the chiasmatic logic behind the two positions: Violet as artistic, oblivious to the ethical; Catharine as concerned with the ethical, forgetful of the artistic dimension.

The doctor listens incredulously when Violet claims her son was chaste; she portrays her son as masked, and also acknowledges he was chased. In addition, in the short play Step Must Be Gentle (a possible hypotext), the mother is aware of her son's homosexual encounters and bemoans them. But then the relation between SMBG and SLS is not straightforward, with many explicit elements from SMBG (the identification of the protagonist with a real life poet, Hart Crane, whom Williams admired, in that case doing away with the speculation about the quality of his work, which is an issue in SLS) being removed or rendered ambiguous in SLS, so that the connection is also slippery.

8. "Most people's lives -what are they but trails of debris, each day more debris, more debris, long, long trails of debris with nothing to clean it all up but, finally, death [...] My son, Sebastian, and I constructed our days, each day, we would -carve out each day of our lives like a piece of sculpture. -Yes, we left behind a trail of days like a gallery of sculpture!" (111)

9. In that respect, I do not subscribe to Siegel's claim that "The suggestion is that once an artist stops creating, he can easily be pulled into the vortex of sensuality that will ultimately destroy him" (545). I would reverse the cause and effect logic. Following Williams' reasoning in his non-fiction, it seems to be the absence of separation between art and life, and in that case the growing rift between the poet's ethereal aesthetic ideals and his lifestyle that stifled his inspiration. While it is plausible that Sebastian's separation from his mother undermined his creativity (although Violet makes clear that they had already -and traumatically for her - been apart before), and cut the symbolic cord of their filial bond, it is more than likely he had already been consumed 
by lust, even during his writing summers. Williams' comments on Sebastian hint at a lasting struggle, not a break from previous practice: "Sebastian? He is completely enslaved by his baser nature and this is what destroys him. His death is a ritualistic death, symbolic. And when he fails, when he is unable to write his poem that summer, then he is completely lost" (Devlin, 210).

10. This is not properly speaking a contradiction, as Williams metaphorically likens oral sex to the Eucharist (see Clum, and Gross), but it does become one when the carnal aspect is left out and a disjunction is created between the terms of the metaphor.

11. "Sometimes the truth is more accessible when you ignore realism, because when you see things in a somewhat exaggerated form you capture more of the true essence of life. The exaggeration gets closer to the essence. This essence of life is really very grotesque and gothic. To get to it you've got to do what may strike some people as distortion." ([1978] Conversations with Tennessee Williams, 264.)

12. This would of course be true of any description, regardless of the medium. But it takes on a particular significance in performance, which is characterized by the possibility to have a live actor stand for an individuality. To not only negate the presence of the character, but to attempt to reconstruct him entirely out of other characters' speeches, i.e. to create an essentially epic persona, goes against the grain of drama and is in itself a mortiferous gesture.

13. "this was Sebastian's garden. The Latin names of the plants were printed on tags attached to them but the print's fading out." (101)

14. Its prevalence as a hermeneutic pivot in Williams' œuvre could warrant another article; let us only notice that the device is more recurrent than exceptional in his work. (e.g. the (Quaa)lude/lewd in "The Killer Chicken and the Closet Queen" (Williams 1985, 602); raising cane (Cain) in "Miss Coynte of Green" (ibid, 524); the eye/I operation in "The Catastrophe of Success" (Williams 2009, 148); and close approximations such as the decade/decayed pair and the ass/asp slip of the tongue in "Sabbatha and Solitude" (Williams 1985, 542 and 550), just to name a few short stories or essays).

\section{ABSTRACTS}

Suddenly Last Summer dramatizes a hermeneutic problem recurrently presented in Williams' critical writings: the separation (or absence thereof) between art and life. While the truth about Sebastian Venable's death seems to be revealed (even if it turns out to be dubious), the possible connection of biography and work remains an unanswered issue, although Violet's stance hinges on this postulate. Using an outwardly simplistic binary framework, Williams in reality builds a network of chiasmatic connections that cancel each other out and render any definite conclusion ineffective. The efficiency of the aporetic demonstration is reinforced by its strict avoidance of didacticism. 
INDEX

Keywords: art, biography, drama, gothic, homosexuality, reception, Suddenly Last Summer, American theatre, 20th century, United States

Mots-clés: art, biographie, gothique, homosexualité, réception, Soudain l'été dernier, théâtre, théâtre américain, XXe siècle, États-Unis

\section{AUTHORS}

MARIE PECORARI

Paris-Sorbonne Université

maître de conférences en anglais/Associate Professor of English

marie.pecorari@gmail.com 